\title{
Lecturing Engineering Ethics for Graduate Students of Civil Engineering
}

\author{
Bayan Salim Al-Numan* \\ Tishk International University, Erbil, Iraq
}

*Corresponding author: Bayan Salim Al-Numan, Department of Civil Engineering, Tishk

International University, Erbil, Iraq.

\author{
Received Date: May 06, 2019 \\ Published Date: May 14, 2019
}

\section{Opinion}

Civil engineering departments issue curricula that consist of fundamental and specialized core courses. These courses provide the students with the required knowledge and skills in various disciplines of civil engineering. Civil engineering is an important branch of engineering and through its related industries, such as the construction industry, is a major contributor to the national GDP for both developing and developed countries. These industries will experience a continuous growth over many years to come because of rising populations, developed technology, construction and reconstruction requirements of infrastructures, and improvements in material science and engineering. It is broadly known that corruption in construction projects (which includes bribery, extortion, embezzlement, kickbacks and fraud) resulted in projects which are unnecessary, unreliable, dangerous, and over-priced. This can lead to loss of life, poverty, economic damage, damaged companies, and damaged individuals. There are claims that corruption accounts for hundreds of billions of dollars worldwide construction costs each year. Transparency International, in its report, in 2013, (https://www.u4.no/publications/iraq-overviewof-corruption-and-anti-corruption.pdf ) mentioned that $40 \%$ of the Iraqi reconstruction projects assessed had major deficiencies, including overcharging by subcontractors, expenditures unaccounted for, waste and fraud. It is important to denote that not only governments, societies, firms, etc. should cooperate and act against corruption, universities and especially their engineering faculties should have their role in fighting corruption by developing courses in professional ethics in their curricula. For civil engineering graduates, their working fields will be in organizations and corporations, public or private, as construction engineers and project managers. The responsibility of these engineers includes submission of ethical professional decisions. Therefore, it is of paramount importance and great need that the curricula in engineering faculties across the country be developed so that engineering students take courses in fundamentals of professional ethics. It was a thoughtful decision by the civil engineering department council at Tishk International University TIU in Erbil, Iraq to address engineering ethics to its graduate students, to my best of knowledge, for the first time in Iraqi engineering faculties. An elective course of "Ethics in Engineering and Construction" CE450 has been announced to graduate students to be within the final 8th semester course load. It is the most suitable semester to put Ethics elective course in, just before graduation. As a professor of structural engineering for over 25 years and never practiced such course lecturing, and I may say that this is never practiced in all Iraqi universities; I found this practice a noble challenge! Amazingly, a high rate of graduate students had registered in the course (29 out of 60); many of them are top students of high GPA, even when they became informed that $40 \%$ of the course will be based on a project-based learning PBL method; a student-centered learning method, which is not familiar to our students in Iraq. This high rate of registration may be explained that some students may felt that the subject would draw answers to the problem of reforming the construction industry. On the other hand, other students may have thought that ethical discussions would be a justified, fruitful station in a semester of heavy design courses.

The Ethics in Engineering and Construction course addresses professionalism, responsibilities, framing and resolving ethical problems, trust and reliability, organizational conduct, and attitude toward environment. The Code of Ethics issued by the American Society of Civil Engineers ASCE is a major chapter in the course. Case studies from literature were discussed through the course, and further studies were asked to be discussed and presented by 
groups of students based on a partial PBL method. It was difficult to address local ethical cases. Interestingly, some female students selected to group-study on women in engineering. In my opinion, in order to seriously address the ethical problems and their solutions, to fight corruption, to provide graduates the capacity of ethical decision-making and in view of students' positive response and reaction, such course on 'ethics in engineering' is worth to be introduced in the programs of all departments in the engineering faculties in Iraq.

\section{Acknowledgment}

None.

\section{Conflict of Interest}

No conflict of interest. 